\title{
PERFORMANSI KINERJA BUDIDAYA PEMBESARAN IKAN LELE SANGKURIANG (Clarias gariepinus) DI CV. DAMPO AWANG KECAMATAN JATINANGOR KABUPATEN SUMEDANG, JAWA BARAT
}

\section{PERFORMANCE OF CATFISH CULTURE (Clarias gariepinus) AT CV. DAMPO AWANG SUB DISTRICT JATINANGOR, DISTRICT SUMEDANG, WEST JAVA}

\author{
Haliyani \\ Politeknik Ahli Usaha Perikanan \\ JI. AUP Pasar Minggu, Jakarta Selatan \\ Email: Lingsyam980@gmail.com
}

\begin{abstract}
ABSTRAK
Ikan lele sangkuriang (Clarias gariepinus) merupakan jenis ikan konsumsi yang memiliki prospek menjanjikan dan mulai merebut perhatian pelaku usaha budidaya. Ikan lele sangkuriang memiliki kelebihan yaitu panen yang cepat, hasil produksi lebih tinggi, lebih tahan terhadap penyakit, sangat mudah dibudidayakan dan teknik pemeliharaannya yang sederhana. Hal ini dilakukan untuk mengetahui performansi budidaya pembesaran ikan lele Sangkuriang (Clarias gariepinus). Pengamatan dilaksanakan selama 2 bulan di CV. Dampo Awang, Kecamatan Jatinangor, Kabupaten Sumedang, Jawa Barat. Pada budidaya pembesaran ikan lele kita harus memperhatikan performa kinerja budidaya tersebut baik dari Pada budidaya pembesaran ikan lele kita harus memperhatikan kinerja budidaya tersebut antara lain adalah produktivitas, Average Body Weight (ABW), Feed Convertion Ratio (FCR) Survival Rate (SR) dan Kualitas air yaitu $\mathrm{pH}$, suhu, amonia, nitrit, nitrat, oksigen terlarut. performansi budidaya pada siklus pertama telah mencapai target namun pada siklus kedua belum mencapai target produksi, hasil tersebut dikarenakan pada rata-rata berat panen dan tingkat kelangsungan hidup yang rendah sedangkan FCR tinggi. Kualitas air untuk $\mathrm{pH}$ berada pada batas layak, demikian pula dengan nilai oksigen terlarut tidak semua kolam berada pada batas layak, sedangkan ammonia, nitrit dan nitrat berada pada ambang normal.
\end{abstract}

Kata Kunci : Produktivitas, lele sangkuriang (Clarias gaeriepinus)

\begin{abstract}
Sangkuriang catfish (Clarias gariepinus) is a type of consumption fish that has promising prospects and is starting to grab the attention of cultivators. Sangkuriang catfish has advantages, namely a fast harvest, higher production yields, more resistance to disease, very easy to cultivate and simple maintenance techniques. This is done to determine the performance of Sangkuriang catfish (Clarias gariepinus) cultivation. Observations were carried out for 2 months at CV. Dampo Awang, Jatinangor District, Sumedang Regency, West Java. In catfish enlargement cultivation, we must pay attention to the performance of the culture, both from the cultivation of catfish enlargement, we must pay attention to the performance of this culture, including productivity, Average Body Weight (ABW), Feed Conversion Ratio (FCR), Survival Rate (SR) and Quality. water namely $\mathrm{pH}$, temperature, ammonia, nitrite, nitrate, dissolved oxygen. Cultivation performance in the first cycle has reached the target but in the second cycle it has not reached the production target, this result is due to the low average harvest weight and survival rate while the FCR is high. The water quality for $\mathrm{pH}$ is at the acceptable limit, as well as the dissolved oxygen value, not all ponds are at the acceptable limit, while ammonia, nitrite and nitrate are at the normal threshold..
\end{abstract}

Keywords: Productivity, sangkuriang catfish (Clarias gaeriepinus) 
Buletin JSJ, 2 (1), 2020, 1-11

Available online di: http://ejournal-balitbang.kkp.go.id/index.php/JSJ/index

\section{PENDAHULUAN}

Ikan lele sangkuriang (Clarias gariepinus) merupakan jenis ikan konsumsi yang memiliki prospek menjanjikan dan mulai merebut perhatian pelaku usaha budidaya. Ikan lele sangkuriang memiliki kelebihan yaitu panen yang cepat, hasil produksi lebih tinggi, lebih tahan terhadap penyakit, sangat mudah dibudidayakan dan teknik pemeliharaannya yang sederhana. Ikan lele sangkuriang merupakan salah satu jenis komoditas ikan air tawar yang sudah dibudidayakan secara komersial oleh masyarakat Indonesia terutama di Pulau Jawa (Nurasni, 2012).

Kebutuhan sumber protein hewani khususnya komoditas perikanan terus meningkat setiap tahunnya sehingga perlu adanya inovasi agar produksi ikan lele biasa meningkat (Jaja dkk, 2013). Lele merupakan salah satu ikan yang mampu bertahan pada lingkungan perairan yang buruk. Air merupakan pelarut yang dibutuhkan oleh seluruh makhluk hidup. Air dibutuhkan oleh makhluk hidup baik secara internal ataupun eksternal. Secara internal, air dimanfaatkan sebagai tempat terjadinya reaksi kimia, transportasi hasil metabolisme dan sebagainya. Sementara secara eksternal, air dimanfaatkan untuk memenuhi kebutuhan sehari-hari baik untuk makan, minum, mencuci dan menjadi habitat bagi organisme air.

Pada budidaya pembesaran ikan lele kita harus memperhatikan performa kinerja budidaya tersebut baik dari Pada budidaya pembesaran ikan lele kita harus memperhatikan performa kinerja budidaya tersebut antara lain adalah produktivitas, Average Body Weight (ABW), Feed Convertion Ratio (FCR) Survival Rate (SR) dan Kualitas air yaitu pH, Suhu, Amonia, Nitrit, Nitrat, Oksigen Terlarut.

\section{TUJUAN}

Mengetahui Performansi budidaya pembesaran ikan lele Sangkuriang (Clarias gariepinus)

\section{BAHAN DAN METODE}

Pengamatan dilakukan selama 2 bulan di CV. Dampo Awang, Kecamatan Jatinangor, Kabupaten Sumedang, Jawa Barat. Kolam yang digunakan adalah kolam bundar berukuran 1,5 m. Benih yang ditebar pada 10 kolam berukuran $6-7$ berasal dari BBAT Sukabumi. Parameter kualitas air yang diamati antara lain $\mathrm{pH}$ dan Suhu yang diukur setiap hari pada pagi dan sore hari, Ammonia, Nitrit, Nitrat dan Oksigen Terlarut yang diukur setiap tujuh hari sekali. Sebanyak 20 sampel ikan dari kolam masing-masing diukur panjangg totalnya. Rumus yang digunakan yaitu ABW (Average Body Weight), FCR (Feed Convertion Ratio), SR (Survival Rate).

$$
\begin{aligned}
& \text { ABW } \frac{g}{\text { ekor }}=\frac{\text { Berat ikan sample }(g)}{\text { jumlah sample ikan }(\text { ekor })} \\
& \mathrm{FCR}=\frac{\text { Total Pakan Yang Dikonsumsi }}{\text { Biomassa (Kg) }}
\end{aligned}
$$


Buletin JSJ, 2 (1), 2020, 1-11

Available online di: http://ejournal-balitbang.kkp.go.id/index.php/JSJ/index

$$
S R(\%) \frac{N t}{N o} \times 100 \%
$$

Keterangan

$\mathrm{Nt} \quad=$ jumlah ikan akhir pemeliharaan (ekor)

No = jumlah ikan awal pemeliharaan (ekor)

$\mathrm{Nt} \quad=$ jumlah ikan akhir pemeliharaan (ekor)

\section{HASIL DAN PEMBAHASAN}

Produktivitas merupakan salah satu faktor penting penentu peningkatan hasil budidaya. Produktivitas kolam budidaya di unit usaha bioflok CV. Dampo Awang. Pada siklus 1 (siklus sebelumnya) perusahaan tidak melakukan pembukuan dengan baik sehingga data yang diambil dengan metode wawancara hasil tersebut digunakan untuk membandingkan hasil siklus sebelumnya dan siklus sekarang. Target produksi perusahaan dapat dilihat pada tabel 1.

Tabel 1. Target Produksi Perusahaan

\begin{tabular}{clcc}
\hline No & \multicolumn{1}{c}{ Indikator } & Satuan & Target \\
\hline 1 & Padat tebar & ekor $/ \mathrm{m}^{3}$ & 400 \\
2 & SR & $\%$ & 98 \\
3 & FCR & - & 1 \\
4 & ABW panen & g/ekor & $100-120$ \\
5 & Lama pemeliharaan & Hari & $70-90$ \\
6 & Target Produksi & $\mathrm{Kg}$ & $800-900$ \\
\hline
\end{tabular}

\section{Produktivitas}

Kisaran produktivitas pada siklus 1 berkisar 40 - $56 \mathrm{~kg} / \mathrm{kolam} / \mathrm{siklus,} \mathrm{dan} \mathrm{siklus} 2$ berkisar antara $16 \mathrm{~kg} / \mathrm{kolam} / \mathrm{siklus} \mathrm{panen} \mathrm{parsial.} \mathrm{Terjadi} \mathrm{penurunan} \mathrm{rata-rata} \mathrm{produktivitas} \mathrm{pada} \mathrm{siklus}$ ke-2. Berdasarkan Gambar 13, produktivitas satu dari lima kolam melebihi target. Namun produksi kolam lainnya dibawah target, sehingga persentase kolam dengan perolehan produktivitas dibawah rata-rata target pada siklus ke-2

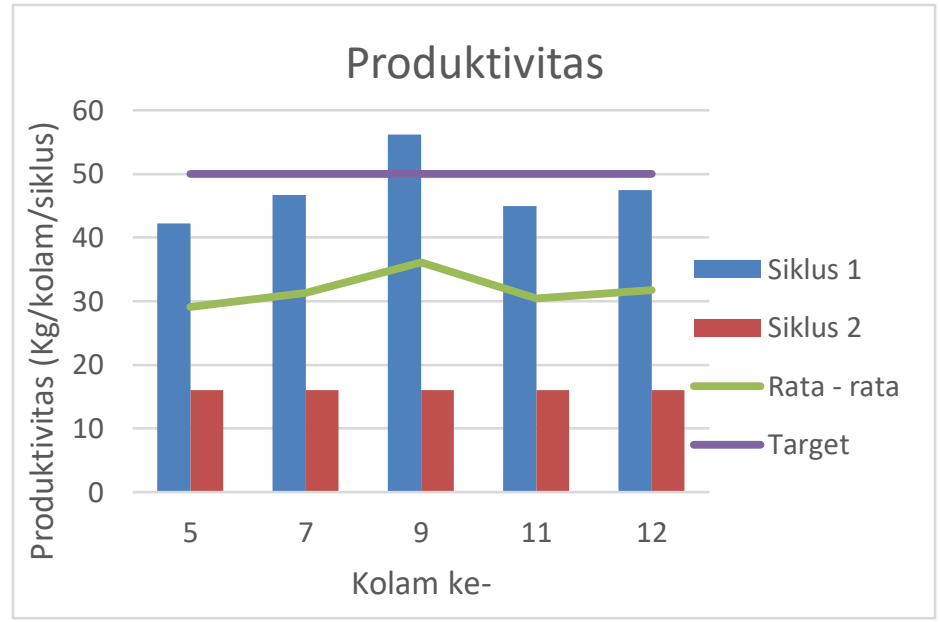

Gambar 1. Hasil Produktivitas Siklus 1 dan 2 
Buletin JSJ, 2 (1), 2020, 1-11

Available online di: http://ejournal-balitbang.kkp.go.id/index.php/JSJ/index

Berdasarkan Gambar 1, produktivitas satu dari lima kolam melebihi target. Namun produksi kolam lainnya dibawah target, sehingga persentase kolam dengan perolehan produktivitas dibawah rata-rata target pada siklus ke-2. Terdapat beberapa faktor yang menyebabkan perolehan rata-rata produktivitas kolam tidak memenuhi target. Rendahnya produktivitas pada kolam dipengaruhi oleh jumlah biomassa panen yang rendah dengan berat rata-rata ikan per ekor yang bervariasi. Berat rata-rata ikan yang bervariasi diduga karena selama proses pemeliharaan tidak dilakukan grading sehingga berpotensi terjadi kanibalisme yang menyebabkan rendahnya jumlah biomassa panen.

Selain itu, rendahnya produktivitas pada siklus 2 dikarenakan serangan penyakit Aeromonas, Yersinia ruckeri, Pseudomonas. yang terjadi pada pemeliharaan, sehingga mortalitas ikan tinggi. Serangan bakteri tersebut terjadi akibat suhu media pemeliharaan yang berfluktuasi. Gejala yang terlihat adalah pendarahan pada tubuh ikan dan kematian yang cukup tinggi.

\section{Average Body Weight (ABW)}

Pada target produksi yang diinginkan perusahaan adalah 10 hingga $12 \mathrm{ekor} / \mathrm{Kg}$. Berat rata rata yang didapatkan pada siklus 1 pada kolam 5 tidak mencapai target sedangkan pada kolam lainnya mencapai target baik dari panen parsial dan setelahnya, perbedaan ukuran dan berat yang ditargetkan perusahaan menyesuaikan permintaan pasar, sehingga FCR yang dihasilkan hampir sama dengan hasil dari panen parsial. Sedangkan pada siklus ke-2 merupakan hasil dari panen parsial. Grafik dari ABW dapat dilihat pada gambar 2.

Terdapat beberapa faktor yang menyebabkan perolehan rata-rata produktivitas kolam tidak memenuhi target. Rendahnya produktivitas pada kolam dipengaruhi oleh jumlah biomassa panen yang rendah dengan berat rata-rata ikan per ekor yang bervariasi. Berat rata-rata ikan yang bervariasi diduga karena selama proses pemeliharaan tidak dilakukan grading sehingga berpotensi terjadi kanibalisme yang menyebabkan rendahnya jumlah biomassa panen.

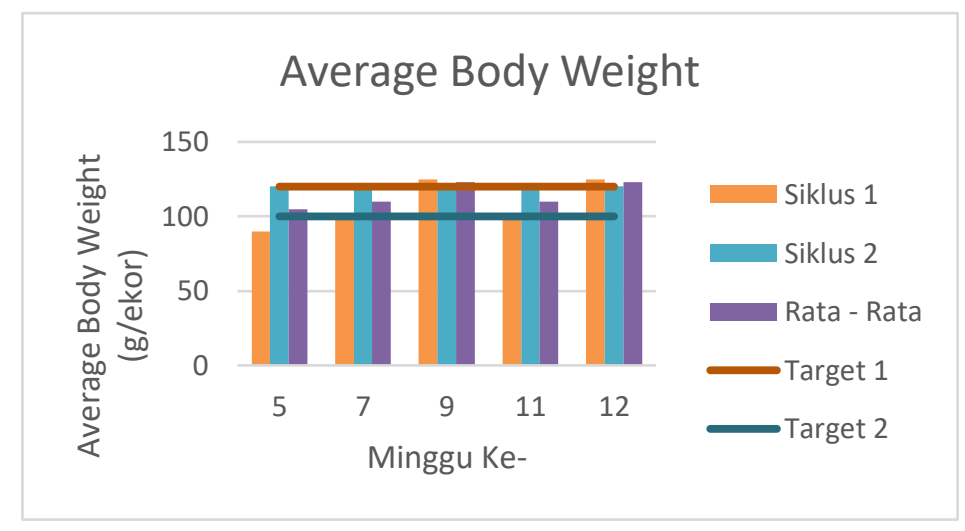

Gambar 2. Perbandingan berat rata siklus 1 dan 2

\section{Survival Rate (SR)}

Tingkat kelulusan hidup atau Suvival Rate pada ikan lele akan mempengaruhi hasil produksi yang akan didapatkan. Perbedaan tingkat kelulusan hidup ikan lele pada siklus pertama dan siklus kedua dapat dilihat pada Gambar 3. Pada siklus pertama, perolehan SR berkisar antara 69- $87 \%$, sedangkan pada siklus kedua SR berkisar pada $33 \%$. Terjadi penurunan rata-rata SR pada siklus kedua. Hal ini karena pada siklus kedua dilakukan panen parsial pada DOC ke-70. Berdasarkan perolehan SR pada siklus pertama dan kedua belum mencapai target sedangkan perolehan rata - rata SR terdapat pada siklus 1. Menurut (Hendriyana, 2010) Tingkat kelangsungan hidup lele sangkuriang (Clarias gariepinus) dapat mencapai $80 \%-90 \%$, 
Buletin JSJ, 2 (1), 2020, 1-11

Available online di: http://ejournal-balitbang.kkp.go.id/index.php/JSJ/index

dengan demikian masih menunjukkan kisaran kelangsungan hidup yang baik selama masa pemeliharaan dapat dilihat pada Gambar 3. Berdasarkan hasil tersebut terdapat 14 kolam yang belum memenuhi pendapat tersebut. Hasil Perbandingan SR dapat dilihat pada gambar Secara umum perolehan rata-rata SR ikan lele yang dipelihara pada semua kolam berada pada kisaran $>77 \%$. Hal ini dianggap cukup sedangkan rata-rata SR ikan lele yang dibudidayakan secara konvensional yang hanya 70\% (Ruherlistyani $d k k, 2017$ ). Namun, SR yang rendah diduga karena pada saat penebaran benih lele tidak dilakukan Quality Control dan aklimatisasi yang benar, sehingga ikan tidak dapat beradaptasi dengan baik dan akhirnya mati.

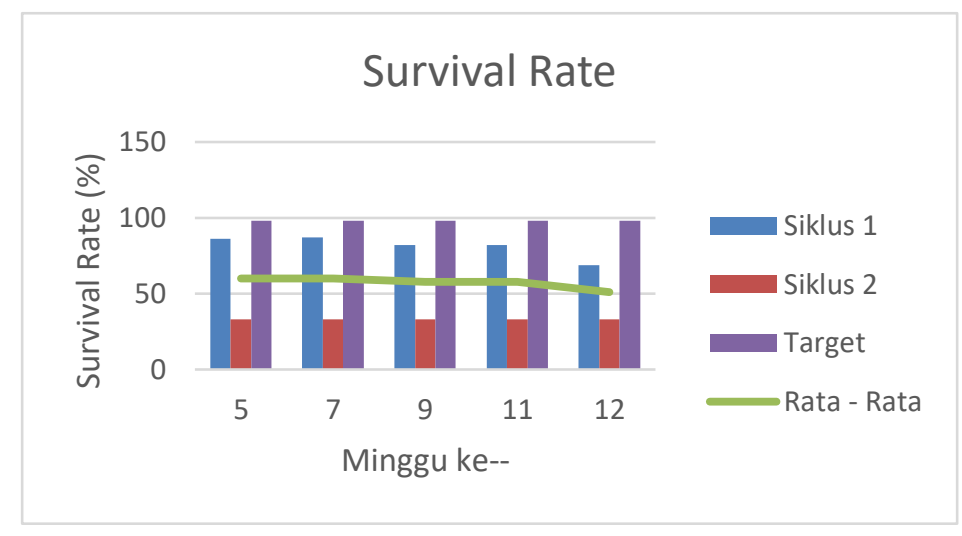

Gambar 3. Perbandingan Tingkat Kelangsungan Hidup

\section{Feed Convertion Ratio (FCR)}

Hasil perolehan FCR bervariasi pada setiap siklus. Pada siklus ke-1 FCR berada pada 0,9 1,1 sedangkan pada siklus ke-2 FCR berada pada 2,3 Berdasarkan Gambar 4, Siklus 1 pada kolam 11 melebihi target sedangkan pada siklus ke-2 pada semua kolam melebihi target, pada hal hasil FCR tersebut merupakan hasil dari panen parsial. Secara umum perolehan rata-rata FCR ikan lele yang dipelihara lebih rendah dari rata-rata FCR ikan lele yang dibudidayakan secara konvensional yaitu 1,1. Hal ini diduga akibat pemberian pakan yang berlebihan sedangkan jumlah ikan yang ditebar akan mempengaruhi jumlah pakan yang akan diberikan. Karena menurut (Hariani dan Tarzan, 2017), faktor yang mempengaruhi tinggi rendahnya efesiensi pakan salah satunya adalah jumlah dan kualitas pakan yang diberikan. Semakin tinggi nilai efesiensi pakan maka respon ikan terhadap pakan semakin baik. Grafik nilai FCR dapat dilihat pada Gambar 4.

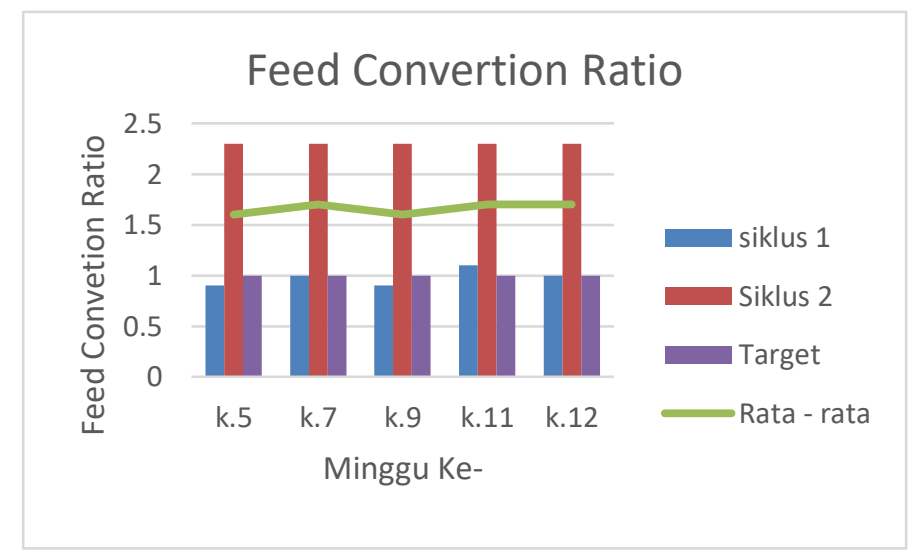

Gambar 4. Perbandingan FCR siklus 1 dan 2 
Buletin JSJ, 2 (1), 2020, 1-11

Available online di: http://ejournal-balitbang.kkp.go.id/index.php/JSJ/index

\section{Kualitas Air}

\section{a. $\mathrm{pH}$}

Selama masa pemeliharaan nilai parameter kualitas air pada masing-masing media budidaya terlihat masih baik. Meskipun secara umum terjadi fluktuasi, namun perubahan yang terjadi masih berada dalam batas toleransi untuk kehidupan ikan lele (Clarias gariepinus.). Parameter tersebut adalah $\mathrm{pH}$ dan suhu. Intensifikasi budidaya dapat berhasil tanpa menurunkan laju pertumbuhan apabila dilakukan pengawasan terhadap empat faktor lingkungan yaitu suhu, pakan, suplai oksigen, dan limbah metabolisme (Abulias, 2014).

Konsentrasi $\mathrm{pH}$ air pada setiap perlakuan berada dalam batas yang layak bagi pertumbuhan ikan lele, berkisar 5 - 9 (PPRI-82/2011). Menurut (Adharani, 2016). pH merupakan salah satu faktor lingkungan yang berpengaruh terhadap pertumbuhan ikan. $\mathrm{pH}$ yang didapatkan selama praktik dengan rata - rata berkisar antara $6-8$ hal ini dapat dikatakan layak pada suatu usaha budidaya dan masih dalam kisaran yang mampu mendukung untuk kehidupan ikan lele. Hal ini sesuai dengan pendapat (Sunarma 2004) bahwa budidaya ikan lele paling baik dilakukan pada $\mathrm{pH}$ perairan yang berkisar antara $6-9$. Menurut (Luo $d k k, 2013$ ) $\mathrm{pH}$ optimal pada penerapan pembesaran ikan lele sangkuriang adalah berkisar 7,5-8,7. Grafik nilai pH dapat dilihat pada Gambar 5.

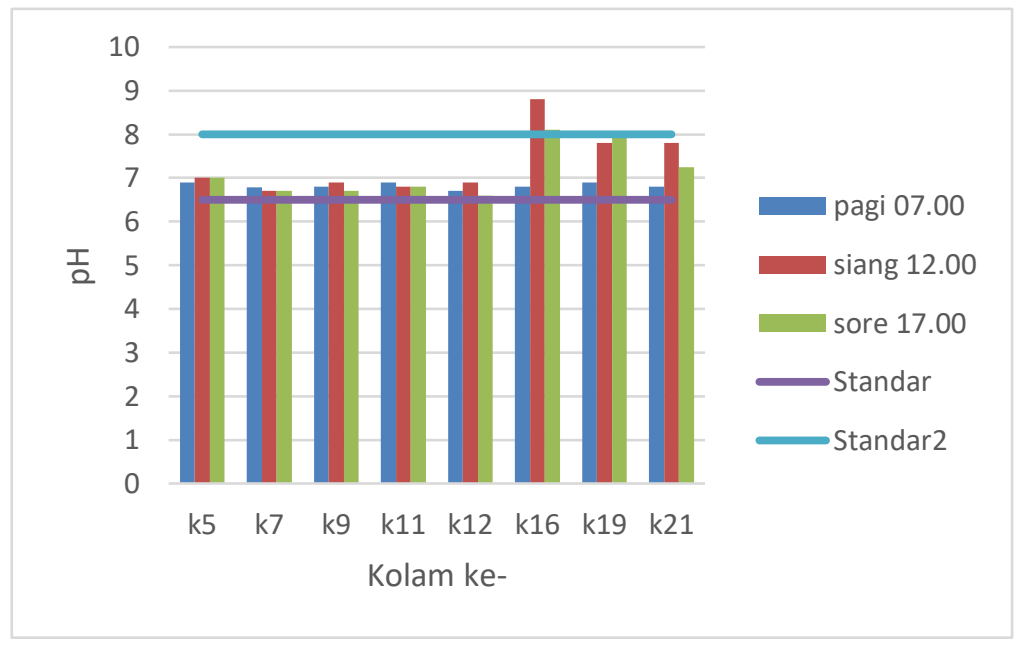

Gambar 5. pH pemeliharaan

\section{b. Suhu}

Pengamatan suhu selama praktik adalah $19-25^{\circ} \mathrm{C}$. Rendahnya suhu pada pagi dan sore hari diduga karena lokasi budidaya yang berada pada lokasi pegunungan. Suhu air pada media pemeliharaan berada dalam batas yang layak bagi pertumbuhan ikan lele adalah berkisar 25 - $30{ }^{\circ} \mathrm{C}$ (Pillay \& Kutty 2005) dan SNI Nomor 6484.3:2014. Suhu sangat berpengaruh terhadap berbagai reaksi kimia dalam badan air, diantaranya adalah berpengaruh terhadap kelarutan oksigen di dalam air dan metabolisme tubuh ikan, sehingga akan mempengaruhi pertumbuhan ikan (Boyd, 1998). Dapat dilihat pada gambar 6. 
Buletin JSJ, 2 (1), 2020, 1-11

Available online di: http://ejournal-balitbang.kkp.go.id/index.php/JSJ/index

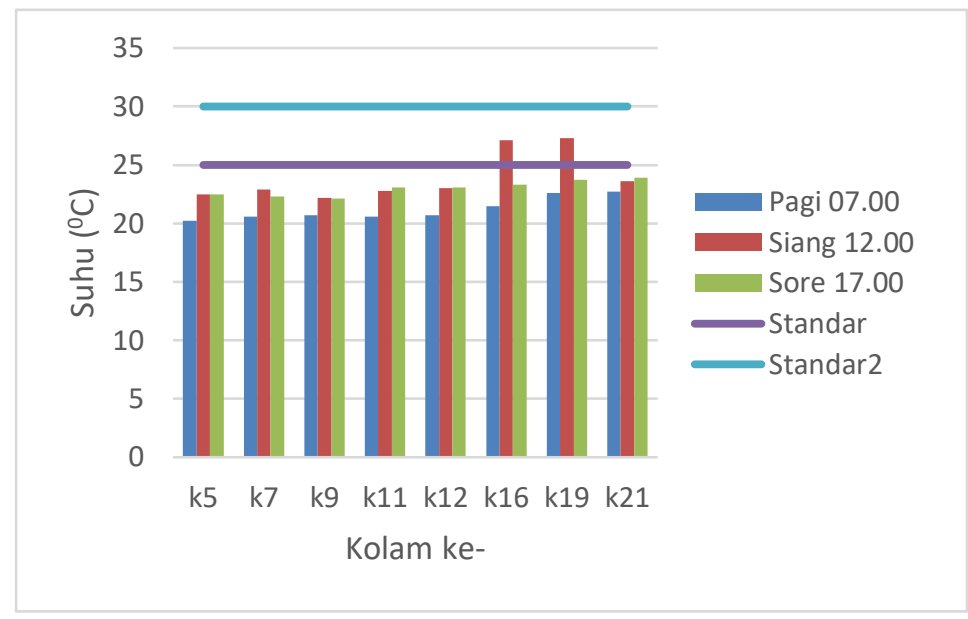

Gambar 6. Suhu Pemeliharaan

\section{Amonia}

Limbah yang sangat berbahaya dan bersifat toksik bagi ikan adalah amonia karena ini sangat berbahaya dan mampu memicu timbulnya racun ataupun penyakit pada ikan. Potensi pasokan amonia ke dalam air budidaya ikan adalah sebesar $75 \%$ dari kadar nitrogen dalam pakan (Gunardi \& Hafsari 2008). Sementara itu, (Boyd 1990) berpendapat bahwa keberadaan amonia mempengaruhi pertumbuhan karena mereduksi masukan oksigen akibat rusaknya insang, menambah energi untuk detoksifikasi, mengganggu osmeregulasi dan mengakibatkan kerusakan fisik pada jaringan. Keberadaan amonia selain dipengaruhi oleh hasil dari sisa metabolisme oleh ikan itu sendiri (Ramadhan, 2015) juga dipengaruhi oleh ketersedian oksigen terlarut yang ada dalam badan air.

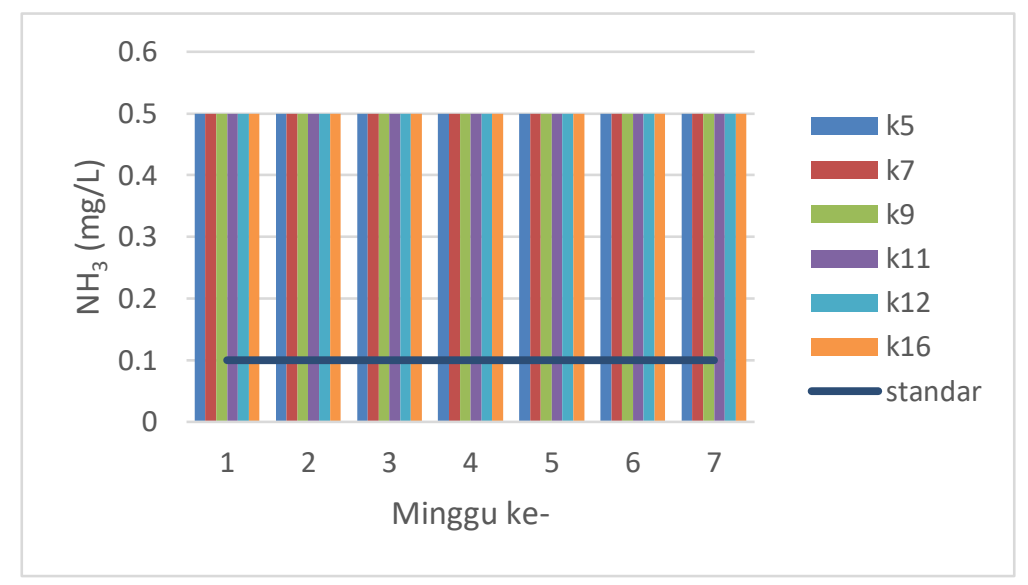

Gambar 7. Hasil pengamatan Ammonia

Pada kolam pemeliharaan terlihat warna air yang pekat, hal ini menandakan bahwa amonia pada kolam sangat tinggi dan memiliki nilai $0,5 \mathrm{mg} / \mathrm{L}$. Hal ini diakibatkan oleh tingginya padat tebar yang mempengaruhi tingginya produksi ammonia. Jumlah organisme yang dipelihara mempengaruhi jumlah pakan yang diberikan serta feses yang dihasilkan oleh ikan. Hal ini sesuai dengan pendapat (Spotte 1970) bahwa sisa pemberian pakan menghasilkan bahan organik yang membentuk amonia. 


\section{Buletin JSJ, 2 (1), 2020, 1-11}

Available online di: http://ejournal-balitbang.kkp.go.id/index.php/JSJ/index

\section{Nitrit}

Nilai nitrit yang terukur selama praktik integrasi adalah $5,0 \mathrm{mg} / \mathrm{L}$. Dapat dilihat pada gambar 7. Berdasarkan PPRI-82/2001, kisaran nitrit yang layak untuk budidaya adalah <0,06 mg/L. Nitrit yang terukur lebih besar dari rentang kelayakan, hal ini dapat membahayakan ikan. Pendapat (Moore, 1991) ambang batas kandungan nitrit untuk budidaya ikan lele yaitu sebesar 0,05 mg/L. Kadar nitrit yang melebihi $0,05 \mathrm{mg} / \mathrm{L}$ dapat bersifat toksik bagi organisme perairan yang sangat sensitif.

Tingginya konsentrasi nitrit diduga selain dipengaruhi oleh akumulasi bahan organik yang ada pada setiap jenis pakan serta hasil metabolisme ikan dalam perairan yang menghasilkan amonia yang kemudian mengalami nitrifikasi sehingga terbentuk senyawa nitrit dalam air. Selain itu, konsentrasi nitrit juga dipengaruhi oleh tidak adanya pemanfaatan atau rendahnya pemanfaatan senyawa nitrit oleh mikroba untuk mengubah menjadi senyawa nitrat. Menurut (Pratama $d k k, 2017$ ) bahwa tingginya konsentrasi nitrit dapat dipengaruhi karena bakteri alami untuk menguraikan dan memanfaatkan nitrit jumlahnya sedikit. Nitrit merupakan bentuk peralihan (intermediate) antara amonia dan nitrat atau dikenal dengan istilah nirifikasi (Effendi, 2003).

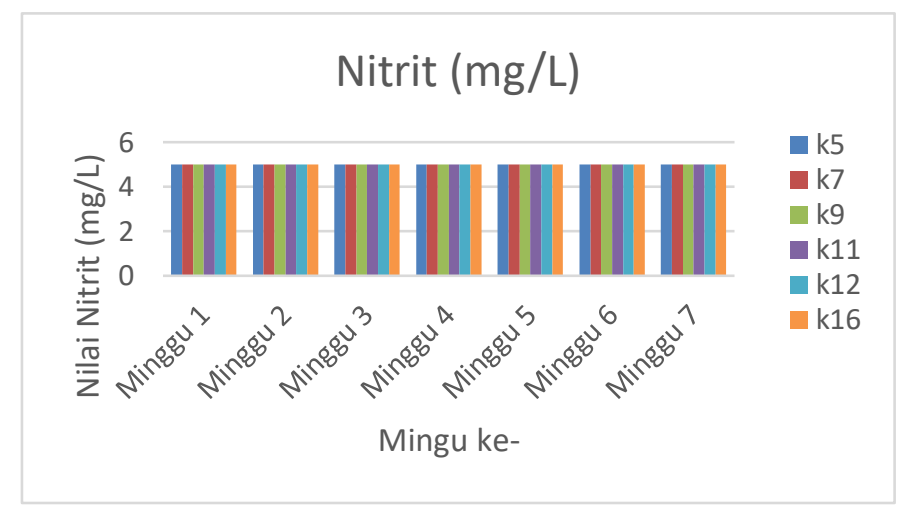

Gambar 7. Hasil pengamatan Nitrit

\section{Nitrat}

Nitrat adalah produksi dari nitrit dalam proses nitrifikasi serta merupakan bentuk oksidasi terbanyak dari nitrogen dalam air (Mayunar, 1990). Rentang nitrat yang terukur selama praktik integrasi adalah $100 \mathrm{mg} / \mathrm{L}$. Dapat dilihat pada gambar 8. Rentang tersebut berada atas kisaran ambang batas untuk budidaya, rentang tersebut menandakan bahwa nitrat yang terukur melebihi $5 \mathrm{mg} / \mathrm{L}$ yang menunjukkan bahwa terjadinya pencemaran antropogenik yang berasal dari feses hewan (Effendi, 2003) kadar nitrat yang lebih dari $0,2 \mathrm{mg} / \mathrm{L}$ dapat menyebabkan terjadinya pengayaan unsur hara perairan (eutrofikasi). Tingginya konsentrasi nitrat bisa diduga senyawa nitrat tersebut sudah ada sebelumnya yang sumbernya berasal dari air dan tanah yang digunakan dalam media pemeliharaan tersebut (Dhiba, 2019). Kandungan nitrat dalam media pemeliharaan berasal dari proses nitrifikasi nitrit menjadi nitrat oleh bakteri nitrifikasi (Stickney, 2005) sehingga konsentrasi nitrat dipengaruhi oleh keberadaan senyawa amonia dan nitrit dalam air. Menurut (Syahrizal $d k k$. 2016) amonia dalam bentuk ion amonium akan mengalami proses nitrifikasi berubah menjadi nitrit dan selanjutnya menjadi nitrat. Perubahan nilai nitrat dapat disebabkan oleh kondisi perairan itu sendiri seperti halnya $\mathrm{pH}$, suhu maupun DO (Pasaribu dkk., 2016). 
Buletin JSJ, 2 (1), 2020, 1-11

Available online di: http://ejournal-balitbang.kkp.go.id/index.php/JSJ/index

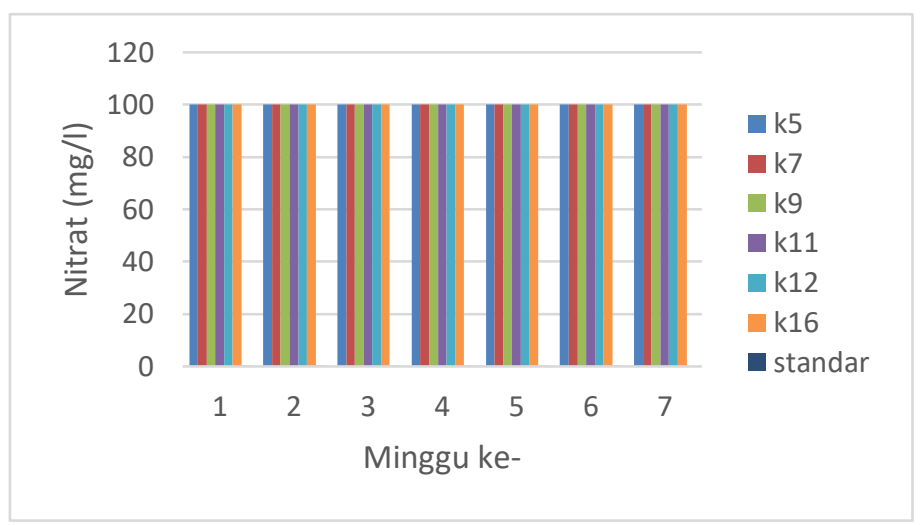

Gambar 8. Nitrat Pemeliharaan

\section{Oksigen Terlarut}

Menurut Stickney (2005), konsentrasi oksigen terlarut yang baik untuk ikan lele tidak boleh kurang dari $3 \mathrm{mg} / \mathrm{l}$. sedangkan menurut pendapat (Avnimelech, 2007) kandungan oksigen terlarut tidak boleh kurang dari $4-5 \mathrm{mg} / \mathrm{L}$. Tetapi pada praktik, oksigen yang dihasilkan berada pada $0,3-1,1 \mathrm{mg} / \mathrm{L}$. Hal ini disebabkan Oksigen yang rendah umumnya diikuti dengan meningkatnya amoniak dan karbondioksida di air yang menyebabkan proses nitrifikasi menjadi terhambat sehingga mengganggu kelangsungan hidup ikan. Rendahnya kadar oksigen yang didapat diakibatkan oleh kurangnya aerasi pada kolam.

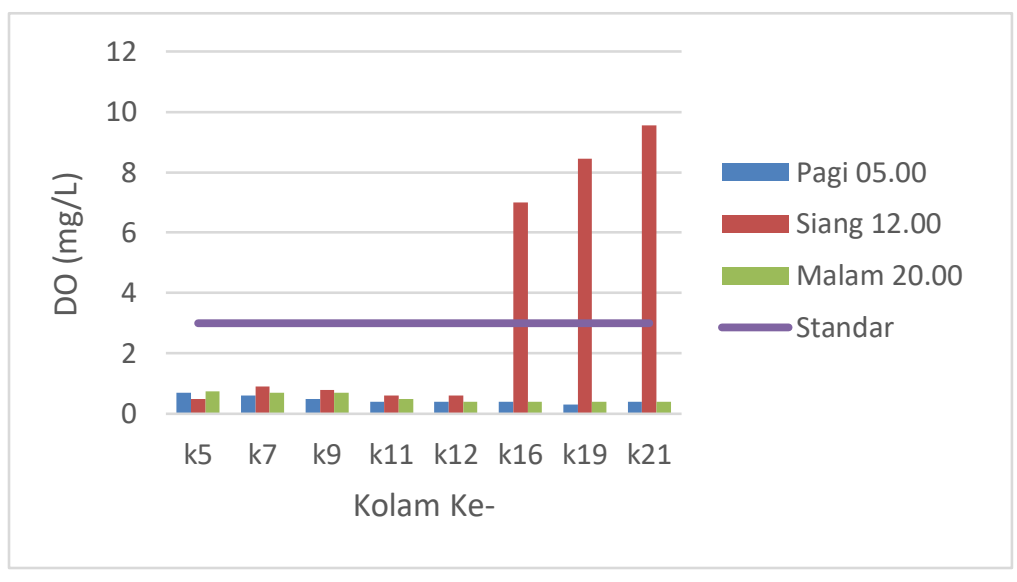

Gambar 9. Oksigen Terlarut Pada Pemeliharaan

\section{KESIMPULAN DAN SARAN}

Performansi kinerja produksi budidaya pada siklus pertama mencapai target, sedangkan pada siklus kedua belum mencapai target produksi, yang mana rata - rata ABW dan SR rendah sedangkan FCR tinggi. Secara umum kualitas air memiliki kisaran yang normal, namun untuk parameter oksigen terlarut perlu mendapat perhatian karena beberapa kolam telah memiliki nilai di bawah batas normal. 
Buletin JSJ, 2 (1), 2020, 1-11

Available online di: http://ejournal-balitbang.kkp.go.id/index.php/JSJ/index

\section{DAFTAR PUSTAKA}

Abulias, M.N., Utarini, D.R.S.R dan Winarni, E.t. 2014. Manajemen Kualitas Media pendederan Ikan Lele pada Lahan Terbatas dengan Teknik Bioflok. Jurnal MIPA 37(1): 16-21.

Adharani, Nadya.,Kadarwan Soewardi, Agung Dhamar Syakti, dan Sigid Hariyadi. 2016. "Manajemen Kualitas Air Dengan Teknologi Bioflok: Studi Kasus Pemeliharaan Ikan Lele (Clarias Sp.) (Water Quality Management Using Bioflocs Technology: Catfish Aquaculture (Clarias sp.))." Jurnal Ilmu Pertanian Indonesia (JIPI), April.

Avnimelech, Y. 2007. Feeding With Microbial Flocs by Tilapia in Minimal Discharge Bio-flocs Technology Ponds. Aquaculture 264: 140 - 147.

Boyd, C.E. 1990. Water Quality in Ponds for Aquaculture. Birmingham Publishing Co: Birmingham, Alabama.

Boyd, C. E. 1998. "Pond Water Aeration Systems." Aquacultue Engineering. Vol. 18. Hal. 940. USA.

Dhiba, Andi Alifia Fara., Syam Husain., Ernawati., analisis kualitas air pada kolam pendederan ikan lele dumbo (clarias gariepinus) dengan penambahan tepung daun singkong (manihot utillisima) sebagai pakan buatan. Jurnal Pendidikan Teknologi Pertanian Volume 5 Maret Suplemen (2019) : S131 - S144

Effendie, H. 2003. "Telaah Kualitas Air Bagi Pengelolaan Sumberdaya dan Lingkungan Perairan." Kanisius. Yogyakarta.

Gunardi B \& Hafsari DR. 2008. Pengendalian Limbah Amoniak Budidaya Ikan Lele dengan Sistem Heterotrofik Menuju Sistem Akuakultur Nir-Limbah. Jurnal Riset Akuakultur 3.

Hariani, Dyah dan Tarzan Purnomo. 2017. "Manajemen Kualitas Air Media Budidaya Ikan Lele Sangkuriang (Clarias gariepinus) dengan Teknik Probiotik Pada Kolam Terpal Di Desa Vokasi Reksosari, Kecamatan Suruh, Kabupaten Semarang." Stigma Journal Of Science 10 (1): 31-35; april 2017.

Hendriana, A. 2010. Pembesaran Lele di Kolam Terpal. Penebar Swadaya.

Jaja, Ani Suryani, dan Komar Sumantadinata. 2013. "Usaha Pembesaran dan Pemasaran Ikan Lele serta Strategi Pengembanganya di UD Sumber Rezeki Parung, Jawa Barat." Jurnal Manajemen Pengembangan Industri Kecil Menengah 8 (1): 45-56. https://doi.org/10.29244/45-56.

Luo, Guozhi, ,Nan Zhang, Hongxin Tan, Zhiwei Hou, dan Wenchang Liu. 2017. "Efficiency of producing bioflocs with aquaculture waste by using poly- hydroxybutyric acid as a carbon source in suspended growth bioreactors.Aquacultural Engineering, 76, 34-40."

Moore, A. 1991. Engineering Analysis of Thestoichiometry of Photoautotrophic, Autotrophic, and Heterotrophic Removal of Ammonia-Nitrogen in Aquaculture Systems. Aquaculture, 257: 346-358.

Nurasni, dan Anisa, Universitas Padjadjaran. 2012. "Pengaruh Suhu Dan Lama Kejutan Panas Terhadap Triploidisasi Ikan Lele Sangkuriang (Clarias gariepinus )” 2 (April): 19-26.

Pasaribu, F.M., Usman, S dan Leidonald, R. 2016. Pengaruh Padat Tebar tinggi dengan Penggunaan Nitrobacter Terhadap Pertumbuhan Ikan Lele (Clarias Sp.).Jurnal Aquacoastmarine 12(2) :1-10.

Ramdhan, M. 2015. Studi Kualitas Perairan Teluk Ekas Berdasarkan Komponen Fisika-Kimia. Social Science Education Journal 2(1) : 58-66. 
Buletin JSJ, 2 (1), 2020, 1-11

Available online di: http://ejournal-balitbang.kkp.go.id/index.php/JSJ/index

Ruherlistyani, D., Sudaryanti, S, dan Heriningsih. 2017. "Budidaya Lele dengan Sistem Bioflok." LPPM UPN VY. Yogyakarta.

Standar Nasional Indonesia (SNI) Nomor 6484.3:2014 tentang ikan lele dumbo (Clarias sp.).

Stickney RR. 2005. Aquaculture: An Introductory Text. Oxford: CABI Publishing, 265 p.

Sunarma, A. 2004. Peningkatan Produktifitas Usaha Lele Sangkuriang (Clarias sp.). Balai Budidaya Air Tawar Sukabumi. Sukabumi. $45 \mathrm{hlm}$

Spotte, S. H. 1970. Fish and Invertebrate Culture: Water Management in Closed System. Wiley Interscience. New York. 145 p.

Syahrizal, Ghofur, M., Safratilofa dan Sam, R. 2016.Tepung Daun Singkong (Monihot utilissima) Tua sebagai Sumber Protein Alternatif dalam Formula Pakan Ikan Lele (Clarias gariepinus). Jurnal Akuakultur Sungai dan Danau 1(1) : 1-11.

Peraturan Pemerintah Republik Indonesia (PPRI) Peraturan Pemerintah Lingkungan Hidup. 2001. Keputusan Menteri Negara Lingkungan Hidup Nomor 82 Tahun 2001 tentang Pengelolaan Kualitas Air dan Pengendalian Pencemaran Air.

Pillay, T.V.R. dan Kutty, M.N. 2005. Aquaculture Principles and Practices. Ed. Ke 2. Oxford (GB): Blackwell Publishing.

Pratama, W.D., Prayogo dan Manan, A. 2017. Pengaruh Pemberian Probiotik Berbeda dalam Sistem Akuaponik Terhadap Kualitas Air pada Budidaya Ikan Lele (Clarias Sp.). Journal of Aquaculture Science 1(1) : 27-35.

Pusat Pendidikan Kelautan dan Perikanan (PUSDIK-KP). 2012. Modul Teaching Factory Pembesaran Ikan Air Tawar. Badan Pengembangan SDM Kelautan dan Perikanan. Jakarta. 